University of Minnesota Morris Digital Well

University of Minnesota Morris Digital Well

4-15-2017

\title{
The Futures of Biofiction Studies
}

Michael Lackey

University of Minnesota Morris, lacke010@morris.umn.edu

Follow this and additional works at: https://digitalcommons.morris.umn.edu/eng_facpubs

Part of the Modern Literature Commons

\section{Recommended Citation}

Lackey, Michael. 2017. "The Futures of Biofiction Studies." a/b:Auto/Biography Studies 32.2: 343-346.

This Article is brought to you for free and open access by the Faculty and Staff Scholarship at University of Minnesota Morris Digital Well. It has been accepted for inclusion in English Publications by an authorized administrator of University of Minnesota Morris Digital Well. For more information, please contact skulann@morris.umn.edu. 


\title{
The Futures of Biofiction Studies
}

\author{
Michael Lackey \\ This is an Accepted Manuscript of an article published by Taylor \& Francis in $\mathrm{a} / \mathrm{b}$ : \\ Auto/Biography Studies on April 15, 2017, available online: \\ https://www.tandfonline.com/doi/full/10.1080/08989575.2017.1288978.
}

That biofiction has become a dominant literary form over the last thirty years is clear. Margaret Atwood (Grace Marks), Michael Cunningham (Virginia Woolf), J. M. Coetzee (Fyodor Dostoevsky), Gabriel Garcia Marquez (General Simón Bolívar), Joyce Carol Oates (Marilyn Monroe), Colum McCann (Rudi Nureyev), Colm Tóibín (Henry James), Peter Carey (Ned Kelly), and Hilary Mantel (Thomas Cromwell) are just a few luminaries who have authored spectacular biographical novels and who have won major awards like the Pulitzer Prize, the Man Booker Prize, the National Book Award, the PEN/Faulkner Award, and many others. But what explains the rise and even dominance of this aesthetic form? And what exactly can this genre do that other forms of fiction cannot? Scholars of biofiction have started to answer these and many other questions, but there is still much work to be done. Having worked on this genre now for more than five years, I want to suggest a few lines of inquiry that might be worth examining.

We know that the aesthetic, political, and epistemological innovations of modernist English writers laid the groundwork for what would become the contemporary valorization and popularity of biofiction. Lytton Strachey and the new biographers revolutionized the biography by making liberal use of the creative imagination and fictional techniques in picturing a person's life, while Virginia Woolf made biography and the biographer a central feature of her novels Orlando and Flush. In essence, Strachey and Woolf nudged the two separate and distinct genres closer to one another. But can we say that Strachey and Woolf paved the way for the current postmodernist literary genre of biofiction, even if neither wrote nor even could imagine their way to a biographical novel? If so, how did Strachey's experimental biographies and Woolf's experimental novels-as-biography set the stage for the rise of biofiction? To what degree did stream of consciousness and the rise of psychology make possible and even necessary the biographical novel? And how do many contemporary biographical novels about Woolf enable us to answer some of these and other questions?

In my estimation, it is impossible to understand the rise and legitimization of biofiction, specifically biblical biofiction, without taking into account the oppressive politics of the early twentieth century. In 1933, Thomas Mann published the first of four novels about the biblical figure Joseph, a tetralogy that challenges readers to think about the potential absurdities and dangers of using a biblical text as the basis for a contemporary political agenda. In 1939, Zora Neale Hurston published a biographical novel about Moses, which many scholars agree offers a scathing critique of the Nazis' treatment of the Jews. Since the 1930s, authors as varied as Frederick Buechner, Anita Diamant, Tóibín, and Geraldine Brooks have authored important biblical biographical novels all for very different political, cultural, and ideological reasons. Is it significant that the biblical biographical novel first became popular in the 1930s during the rise of Hitler and the Nazis? Is there something in the nature of the biblical biographical novel that 
makes it best suited to engage the historical and to critique the political? If so, what is that something? And how has the form of the biblical biographical novel evolved from Mann and Hurston through Buechner and Diamant to Tóibín and Brooks?

In recent years, scholars have authored some important studies of biofiction about individual figures: Monica Latham (Virginia Woolf), Julia Novak (Elizabeth Barrett Browning), and Laura Marcus (Katherine Mansfield) are just a notable few. But what makes a specific historical figure particularly suitable as the protagonist of a biographical novel? How does contemporary biofiction shape the contemporary understanding of a figure from the past? And how do authors' historical and cultural orientations impact their portraits of a biographical subject?

There is certainly a need for more studies about famous figures who appear in multiple biographical novels, such as Eliza Lynch, Friedrich Nietzsche, Emily Dickinson, Ludwig Wittgenstein, Abraham Lincoln, and Nat Turner, but it is also time for studies about the way biofiction enables us to formulate new ways of thinking about major historical events and periods. To illustrate, let me briefly discuss the case of Barbara Chase-Riboud's biographical novel Sally Hemings, which was published in 1979. Rumor had it that Thomas Jefferson was romantically involved with his slave Sally Hemings and that he fathered many children with her. In 1974, Fawn Brodie published a biography about Jefferson, which offered evidence to support this view. Chase-Riboud used Brodie's biography among other works to construct a compelling biographical novel about the thirty-eight-year relationship, but Jefferson scholars dismissed the book as sensationalist fantasy. As Gordon S. Wood claims, "Even those historians willing to accept that Jefferson, like other Southern slaveholders, might have slept with his slaves have balked at the notion that Jefferson had a romantic and long-lasting love relationship with Hemings" (824). But in 1997, Annette Gordon-Reed published Thomas Jefferson and Sally Hemings: An American Controversy, a book that compellingly demonstrates that Jefferson and Hemings had a long-term relationship and which credits Chase-Riboud's novel for changing the way people think about the relationship. So convincing was Gordon-Reed's book that it led professor of pathology Eugene A. Foster to carry out DNA testing, which confirmed that Hemings's descendants are related to Jefferson. This subsequently led Gordon-Reed to publish The Hemingses of Monticello in 2008, a brilliant study that persuasively illustrates that people in Jefferson's time and situation did in fact have long-term, loving, and romantic relationships with people like Hemings. In short, what prominent historians once assured us was inconceivable is now considered the most likely scenario, and it was a biographical novelist who significantly contributed to this reversal in our historical thinking.

To what degree did Chase-Riboud's novel, which sold more than a million copies, shape the cultural ethos in such a way that late-twentieth-century Americans could imagine Jefferson having a thirty-eight-year relationship with Hemings? And to what degree did Chase-Riboud's novel make possible Gordon-Reed's spectacular books? I'm not suggesting that Chase-Riboud gave Gordon-Reed any new documentary evidence or historical facts that enabled her to do her studies. I am suggesting that Chase-Riboud, as a novelist, has an expertise in discerning and representing the strange logic of character, and thus she was able to recover to some degree a 
cultural ethos in which the Jefferson-Hemings relationship was possible and even likely. In essence, Chase-Riboud contributed to the historical record by giving readers a believable portrait of Jefferson and Hemings, and subsequent evidence confirms some (not all) of her suspicions, despite the objections of many prominent historians.

Like the best historians, the most gifted biographical novelists are experts who give readers certain types of "truths." But what kind of experts are they? And what kind of "truths" do they give readers? How are those "truths" different from the ones found in history books? And how can the "truths" of biofiction supplement the historical record or redirect the scholarly conversation? To be more specific, can biofiction give us new insight into the life of Octavius Caesar and ancient Rome (John Williams's Augustus), Hildegard von Bingen and twelfth-century Germany (Mary Sharratt's Illuminations), Ibn Khaldun and fourteenth-century Egypt (Bensalem Himmich's The Polymath), Fyodor Dostoevsky and nineteenth-century Russia (Leonid Tsypkin's Summer in Baden-Baden), Egon Schiele and early-twentieth-century Austria (Joanna Scott's Arrogance), Virginia Woolf and British modernism (Susan Sellers's Vanessa \& Virginia), or Madame Mao Zedong and Communist China (Anchee Min's Becoming Madame Mao)? Studies that would answer these and many other questions are waiting to be done.

\section{Acknowledgments}

Thank you to the University of Minnesota; the University of Minnesota, Morris; and the University of Minnesota's Institute for Advanced Study for funding and supporting the research for this project. I would also like to thank Annette Gordon-Reed, Ricia A. Chansky, Emily Hipchen, and Krista Roberts for reading an early draft of this essay and making useful suggestions for revision.

\section{Works Cited}

Wood, Gordon S. “Gordon S. Wood Replies.” Callaloo 32.3 (2009): 823-25. Print 